\begin{tabular}{|l|l|l||}
\hline \multicolumn{2}{|c|}{ PublisherInfo } \\
\hline \hline PublisherName & $:$ & BioMed Central \\
\hline \hline PublisherLocation & $:$ & London \\
\hline \hline PublisherImprintName & $:$ & BioMed Central \\
\hline \hline
\end{tabular}

\title{
Methylated but noisy
}

\begin{tabular}{|l|l|l||}
\hline \multicolumn{2}{|c|}{ ArticleInfo } \\
\hline \hline ArticleID & $:$ & 3686 \\
\hline \hline ArticleDOI & $:$ & $10.1186 /$ gb-spotlight-20000518-02 \\
\hline \hline ArticleCitationID & $:$ & spotlight-20000518-02 \\
\hline \hline ArticleSequenceNumber & $:$ & 123 \\
\hline \hline ArticleCategory & $:$ & Research news \\
\hline \hline ArticleFirstPage & $:$ & 1 \\
\hline \hline ArticleLastPage & $:$ & 2 \\
\hline \hline & & RegistrationDate : 2000-05-18 \\
ArticleHistory & $:$ & OnlineDate $\quad 2000-05-18$ \\
\hline \hline ArticleCopyright & $:$ & BioMed Central Ltd2000 \\
\hline \hline ArticleGrants & $:$ & \\
\hline \hline ArticleContext & $:$ & 130591111 \\
\hline \hline
\end{tabular}




\section{William Wells}

Email: wells@biotext.com

Interfering with DNA methylation in the plant Arabidopsis, as in animals, disrupts transcriptional gene silencing. But the reverse is not necessarily true. In the 11 May Nature Amedeo et al. describe the first plant or animal gene that, when inhibited, results in disrupted silencing but intact methylation (Nature 2000, 405:203-206). They find the gene, MOM1, by looking for expression from a silenced drug-resistance locus after a random-insertion mutagenesis. The most noticeable homology in MOM1 protein is to the ATPase/helicase region of the SWI2 silencing protein. MOM1 may aid in silencing by acting either downstream or independent of methylation.

\section{References}

1. Demethylation-induced developmental pleiotropy in Arabidopsis.

2. Nature Genetics, [http://www.nature.com/nature/] 